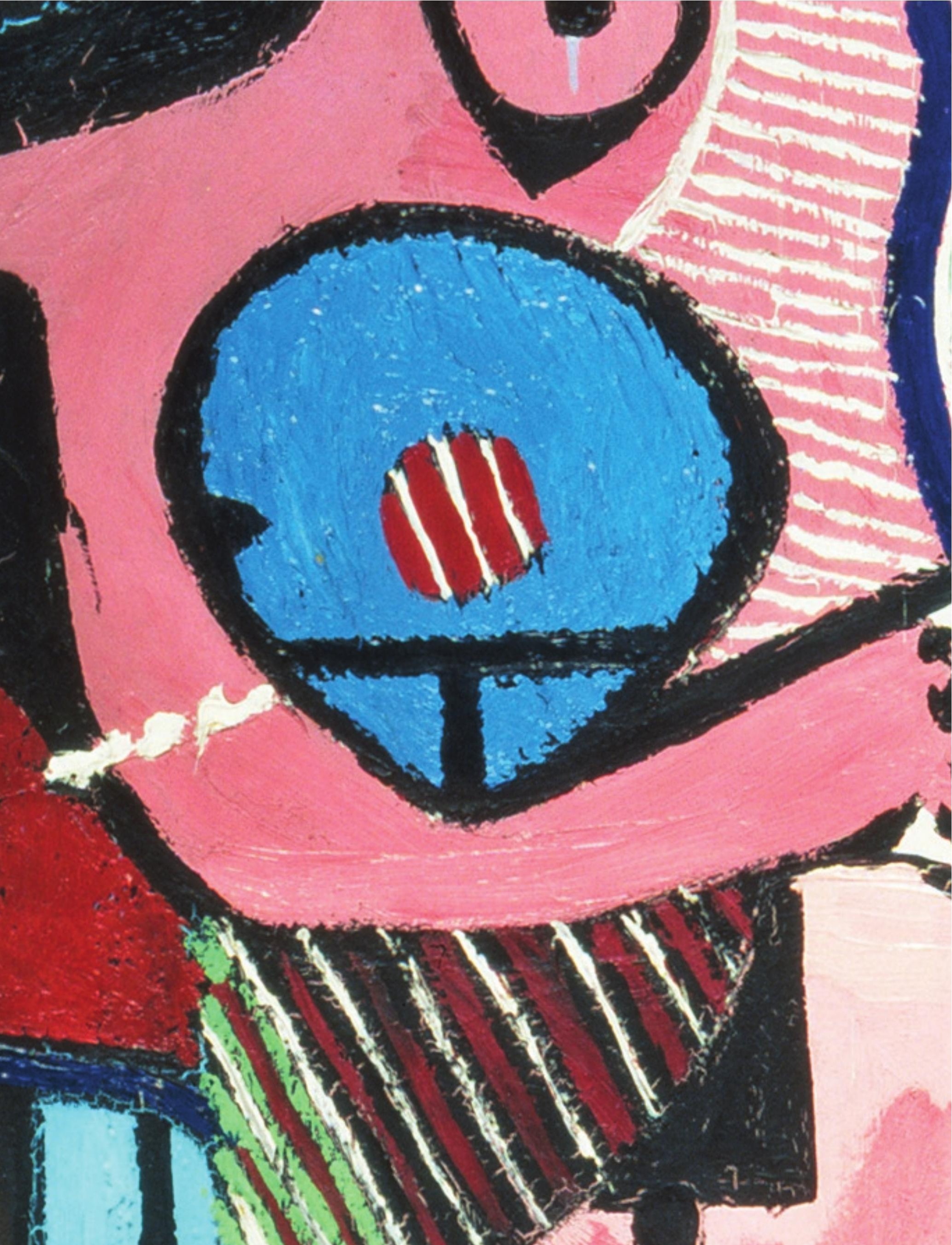




\title{
Rotten Sun
}

\author{
C. F. B. Miller
}

\section{Prologue}

A long time ago an Artist made a Sun in a Great House of Art. The people loved it and came to bask in its glory. They felt the power of the House in this little Sun. The Sun cast its rays East and West to the Prison Tower and the Palace of Governance.

In the half-light across the river the Sick Pigeon watched from a gutter and vomited. 'Why', she asked the Rat, 'is this Sun so beautiful? I have no feet, and my bald skull crawls with lice.' The Rat did not answer, for he was sore afraid, and did chew an old burger. 'I will go to the Sun', said the Pigeon, 'and I will meet it in itself.' But the Rat spluttered. 'You must not', he whined. 'It is a trick.'

But the Pigeon was full of purpose. 'I will fly to the Sun', she said, 'and meet its glory.' The Rat said, 'Your wings are filthy and ragged and without many feathers.' The Pigeon answered, in a terrible voice, 'But I am determined, and seek the Ideal.' 'So be it', said the Rat, 'you will find what we all seek without knowing it.' And he ran up a drainpipe into the Courts of Justice.

Papers fluttered in the gutter. They were called The Sun. The Pigeon took it as a sign and summoned her strength and that of her ancestors and scrabbling footless in white-collar grime she flailed her broken wings forwards, upwards, till her tattered body lurched and twirled against the orange glow of the night sky. 'I will ascend to the Sun!' she cried in triumph, flapping crazily past the marble portals of the Church of Scientology, and out, buffeted by tidal gusts, over the dirty old river. 'I will know true goodness!'

On a high platform in the House of Art the Boss stood up before the Sun. An audience of the great and the good was silent for the first Word of his Speech. His eyes were glass and his voice was as a laser. He spoke of honour, glory and social blessings. Beneath him merchants, moneymen and artists clapped their hands.

Swinging in the river air the Pigeon coughed up blood. The parasites inside her burrowed deeper and her cancers ached. Ahead the portal where the Sun begat its rays burned on the water, casting out a carpet of flame, a line of destination. The House of Art was open, and its glory shone about. The Pigeon was despairing, she could feel her heart give out, she thought she might not make it but her tattered wings a horrid blur she burst into the Great Hall to the shrieks of the assembled guests. At that moment the Boss lifted his glass and opened his mouth to praise his sponsors and - in an instant, a spiny black flash of filthy splay and beak - she stuffed his face with her whole rotten body. There, before the Sun.

10.1111/j.1467-8365.2010.00825.x 


\section{The Picasso Myth is a Solar Myth}

Deep down, all that matters is self. Self is a thousand-rayed sun in the stomach. The rest is nothing. ${ }^{1}$ (Picasso)

At daybreak, the Picasso myth was a solar myth. It arose with Apollinaire - a nomde-plume self-styled for Apollinaris, Apollonius ('Icarus Enoch Elias Apollonius of Tyana'), ${ }^{2}$ Apollodorus, Apollyon; but above all for Apollo, Phoebus, the Shining One. ${ }^{3}$ A pollinator too, of heliotropes in Picasso's name, such as an apostrophe - 'O fecund joy'! - to eyes 'like flowers that wish to contemplate the sun forever'. ${ }^{4}$ For Apollinaire, Picasso

... ranks among those of whom Michelangelo said that they deserve the name of eagles, because they surpass all others and pierce through the clouds until they reach the sunlight.

And today all shadows have disappeared. The last cry of the dying Goethe 'More light!' - echoes in the sublime and mysterious work of a Picasso, as it still echoes in the work of Rembrandt. ${ }^{5}$

Except at night, shadows disappear only at high noon. Michelangelo, Rembrandt, Goethe - the lamp of inspiration passes to Picasso like a little sun. The Romantics likened self-expression to the outpourings of a Neoplatonic heliomorph; creation as the radiation of a solar Supreme Good. ${ }^{6}$ Later in the arc to Decadence, Icarus would stand (or fall) for the artist-poet's doomed trajectory towards the absolute. ${ }^{7}$ Yet here Picasso is the eagle, Zeus's pecker, soaring into correlation with the ideal. 'The eagle,' wrote Georges Bataille in 1930, is allied

... with the sun, which castrates all that enters into conflict with it (Icarus, Prometheus, the Mithraic bull). Politically the eagle is identified with imperialism, that is, with the unconstrained development of individual authoritarian power, triumphant over all obstacles. And metaphysically the eagle is identified with the idea. ${ }^{8}$

At a certain mythological or theological point, God, the Artist, the Genius and the Dictator coincide. 'Every divinity creates in its own image', wrote Apollinaire; 'so it is with painters. ${ }^{\prime}$

The figure of the eagle implies specular ideality. According to a classical tradition of which Michelangelo and Apollinaire were surely aware, only the eagle among sighted creatures could hold the sun's gaze. ${ }^{10}$ When, recalling his dark time at Sonnenstein, Judge Schreber claimed this privilege, Freud deployed the eagle as a mythological vehicle for the Oedipal circuit. Schreber, like Goethe, Turner, Jung and numerous Nazis, believed the Sun to be God. ${ }^{11}$ 'Thou canst not see my face: for there shall no man see me, and live,' announced Yahweh in Exodus. ${ }^{12}$ Schreber begged to disagree; he would look the sun that fucked him, in the eye. The paternal function of the sun in Freud's scheme was systemic enough for him to disclaim 'all responsibility for the monotony of the solutions provided by psychoanalysis' when he said that the sun was 'nothing but another sublimated symbol for the father. ${ }^{13}$ As we shall see, the sun itself might be an object of sublimation. 
To gloss what he called Schreber's ‘solar myth', Freud adduced Salomon Reinach's mythography of the ancient nexus between eagle and sun:

The eagle, then, who makes his young look into the sun and requires of them that they shall not be dazzled by its light, is behaving as though he were himself a descendant of the sun and were submitting his children to a test of their ancestry. And when Schreber boasts that he can look into the sun unscathed and undazzled, he has rediscovered the mythological method of expressing his filial relation to the sun, and has confirmed us once again in our view that the sun is a symbol of the father. ${ }^{14}$

Parallel inscriptions of the sun as divinity and phallus extend throughout the longnineteenth-century text of comparative religion and mythology (a discourse with which Schreber was conversant). ${ }^{15}$ The psychoanalytic refastening of these strands might indicate not only their currency at the time, but the pull of homology at a general level of phallocentrism or the metaphysics of presence; at the level of what Schreber called the 'controlling sun, of which our astronomy knows nothing."16

At the Western end of Picasso's trajectory, in 1969, Rafael Alberti - his last poet, as Apollinaire was his first - extolled the octogenarian painter's undimmed potency:

For you every day begins like a powerful erection, an ardent

Lance pointing

At the rising $\operatorname{sun}^{17}$

Alberti - author of the 1974 title, Picasso, le rayon ininterrompu (Picasso, the uninterrupted ray) - makes explicit the chain of mastery between artist, phallus and sun, and indeed time and again the Picasso mythology has shown itself to be a solar system. Instances of fire and light imagery in the literature are too many to mention - from the 'enormous flame' by which Apollinaire figured Picasso's production in Les Peintres cubistes, ${ }^{18}$ to John Richardson's recent mystification of the artist as a disciple of the Roman solar deity Mithras. ${ }^{19}$ The panegyrics overlook the dark side of the sun. It is customary, when paying homage, to avert one's gaze. Zenith bodes no fall in Apollinaire's figure of flight. As an eagle Picasso need fear no glare. If he is its offspring, he is to the sun as it was to the good, in Plato's eyes. For its part -in the name, perhaps, of the Creative Parts of every Author - Alberti's morning glory disavows the dwindling of Picasso's light, the setting of his sun.

One text sites death in the meridian. I'm referring to Georges Bataille's contribution to Documents magazine's 1930 Hommage à Picasso: 'Soleil pourri' ('Rotten Sun'). It's a brief, stunning flash: two paragraphs, little more than five hundred words, densely plural in their implications. The short format recalls entries in the Dictionnaire critique, the mock-Encyclopédie at the bleeding edge of Documents' 'war-machine against received ideas. ${ }^{20}$ The mode is mash-up - mythemes, philosophemes, archaeologemes, autobiographemes, metapsychologemes - in the manner of what Bataille elsewhere called his 'mythological anthropology'. ${ }^{21}$ The matter is a cosmic split: between the ideal sun of metaphysics, and its real, blinding other. The latter's character, for Bataille, is sacrificial; and something like this sacrificial solar blinding, he suggests, takes place in Picasso's painting.

It is a signal juncture in the history, influentially mapped by Martin Jay, of antiocular thought in twentieth-century France; a flashpoint in the series of attempts by artists, writers and philosophers to interrupt and disassemble the age-old metaphor 
I Pablo Picasso, The Three Dancers, 1925. Oil on canvas, $215.3 \times 142.2 \mathrm{~cm}$. London: Tate. Photo: @ Tate, London 20I0/Succession Picasso/

DACS London 2010. of knowledge as vision. ${ }^{22}$ A tracery of retinal burns constellates Bataille's heliopoetics with the early Derrida, and with Rosalind Krauss's subsequent post-formalist formulation of an anti-visual 'unconscious' in modernist opticality. ${ }^{23}$ At the end of the 1960s Derrida drew on Bataille to deconstruct the hierarchies of traditional (ocularcentric) philosophy. Then, in the 1980s, the deconstructive turn in American art history rediscovered Documents. Krauss's alliance with Denis Hollier - the editor of the Bataille Oeuvres complètes, who had participated with Derrida in the network around the radical journal Tel Quel - was a decisive factor in the orientation of the MIT Press periodical October towards the end of the last century. One result was Krauss's reactivation of the non- or anti-concept informe described by Bataille in Documents, in order to transgress her mentor Clement Greenberg's modernist metaphysics. 'Rotten Sun' lurks at the margin of this story, its historicity occluded. To reread 'Rotten Sun', to write its history, might be not only to unpick traits of production, distribution, archive, but to refold them into the texture of deconstruction, around the triple loop of transmission between Bataille, Tel Quel and October. It might also be to rewrite Picasso into this history. Here, however, whereas Krauss targeted 'form', my matter is the idea.

This special issue conjoins art history and 'creative writing'. Creative writing - is it not a pleonasm? Is to write not in itself creative? Usage would suggest otherwise. The OED tells us that this early twentieth-century collocation restates Romantic notions of 'creative Art' - notions, that is, of an expressive individual Creator. (In the Middle Ages a human being categorically could not be said to create: creatura non potest creare, said Augustine. The Renaissance Genius and his progeny annexed this authority.) $)^{24}$ Creation, origin, filiation: 'Rotten Sun' calls all into question, transgressing the Platonic origin of being, essence and truth. Bataille diverts (perverts) expression and creation towards excretion and destruction. And yet Romantic and Nietzschean myths of the artist-hero inhere in his mythology of sovereignty.

The OED equates creative writing with 'invention and imagination', as 'exhibiting imagination as well as intellect, and thus differentiated from the merely critical, "academic", journalistic, professional, mechanical etc., in literary or artistic production.' That merely is telling. It implies the prestige of having transcended the instrumental or the academic into the aesthetic domain. But the distinction cuts both ways, for the academic constitutes itself against creative writing or poetic language, against a purple prose or belle lettrisme associated with discursive waste and the pseudos. Historiography and theory retain ideals of economy, self-control and objectivity. The academic/creative binary echoes those between logos and mythos, objective and subjective, truth and fiction. Bataille's readers from André Breton and Jean-Paul Sartre onwards have found that his writing troubles such distinctions, and so it is with 'Rotten Sun', which mixes fantasy with the languages of psychology, archaeology and mythography, destabilizing conventions of reference. That is to say, in 'Rotten Sun' Bataille mixes academic discourse with 'creative' - or destructive - writing. In his own life Bataille embodied the contradiction between scholar and transgressor, the Cabinet des médailles and the Histoire de l'oeil, philosopher and mystic. Documents itself was an 'impossible' mixture of disciplines and indisciplines, professional ethnographers and dissident surrealists. ${ }^{25}$

This is not the place for a biographical account of the imbrication between Picasso and Documents. ${ }^{26}$ There is one to be written, though the documentary record is slight. Notwithstanding the ambiguous editorial structure of the magazine, ${ }^{27}$ and the fact that personal communication most likely went through their mutual friend Michel Leiris, Bataille must have chosen the 'illustrations' for 'Rotten Sun', including The Three Dancers of 1925 (eye-boggling lustre!) (plate 1). Though it operates at a tangent 


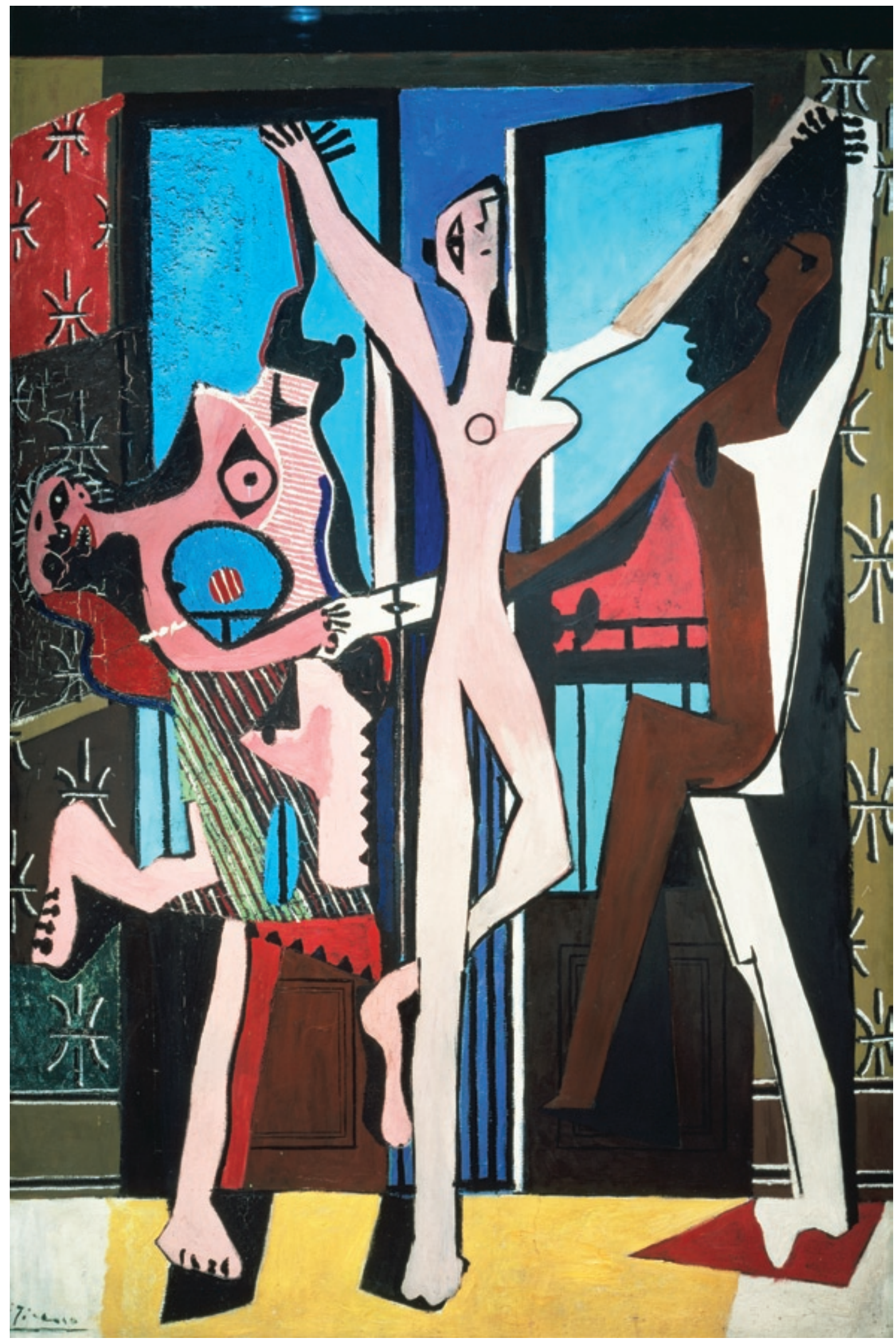


to Picasso's production, 'Rotten Sun', as I see it, enacts what Bataille saw in Picasso; and the lineaments of this enactment are the vectors of my reading.

One ought to read 'Rotten Sun' in one:

The sun, humanly speaking (that is to say insofar as it merges with the notion of noon) is the most elevated conception. It is also the most abstract thing, since it is impossible to behold it fixedly at that time of day. In order to describe the notion of the sun in the mind of one who necessarily has to emasculate it due to the incapacity of his eyes, that sun must be said to have the poetic meaning of mathematical serenity and spiritual elevation. If, on the other hand, despite everything, it is focused on quite obstinately, this implies a certain madness and the notion changes meaning because it is no longer production that appears in the light, but waste, that is to say combustion, well enough expressed, psychologically, by the horror radiating from a blazing arc-lamp. In practice the scrutinised sun can be identified with mental ejaculation, foam on the lips, and the epileptic crisis. In the same way that the preceding sun (that which is not beheld) is perfectly beautiful, that which is beheld may be considered horribly ugly. Mythologically, the viewed sun is identified with a man who slits a bull's throat (Mithras), with a vulture that eats the liver (Prometheus); the viewer with the slaughtered bull or eaten liver. The Mithraic cult of the sun led to a very widespread religious practice: one stripped naked in a sort of pit covered with a wooden lattice on which a priest slit a bull's throat; thus all of a sudden one had a lovely shower of hot blood, accompanied by the din of the bull's struggling and bellowing: a simple means of morally reaping the benefits of the blinding sun. Of course the bull himself is also for his part an image of the sun, but only with his throat cut. The same goes for the cock, whose horrible, particularly solar scream is always close to a scream of slaughter. One might add that the sun has also been expressed mythologically by a man slashing his own throat, and, lastly, by an anthropomorphic being deprived of a head. All of which leads one to say that in practice the apogee of elevation merges with a sudden fall of unprecedented violence. The myth of Icarus is particularly expressive from this point of view: it clearly splits the sun in two - that which was shining at the moment of elevation, and that which melted the wax, causing failure and a screaming fall when Icarus came too close.

The human attitude's distinction between two suns is of particular importance due to the fact that, in this case, the drive [impulsion] of the psychological movements described has not been diverted and attenuated by secondary elements. But this indicates, on the other hand, that it would be a priori ridiculous to attempt to determine the precise equivalents of such movements in an activity as complex as painting. Nevertheless, one might say that academic painting corresponds to an elevation of spirit without excess. In contemporary painting the search for a rupture of elevation taken to its limit [son comble], and for a blinding claim to brilliance [un éclat à pretention aveuglante], has a share in the elaboration or decomposition of forms, though, strictly speaking [à la rigueur], this is perceptible [sensible] only in the painting of Picasso. $^{28}$

Bataille is circumspect about determining the function of the blinding sun and its psychology - between which he implies an unmediated relation - in the second- 
order representation of painting. Yet the same condition applies to the text itself. The blinding sun is unrepresentable. Nevertheless the reader encounters it in the text. Entering discourse, it becomes a verbal image - but an impossible one. It is indeed ridiculous to attempt to determine precise equivalents of the blinding sun. Truth as the determination of correspondence is precisely what the blinding sun ruptures, with a cackle or a scream. 'Rotten Sun' mimics the veridical register of the psychologist or mythologist, yet unsettles the order of reference between text and world, reason and experience. In describing the effects of the blinding sun, it enacts them.

I want to argue that 'Rotten Sun' narrates and performs an anti-idealist practice of looking, whereby the reader experiences what the viewer, in Bataille's eyes, might undergo in looking at a certain kind of Picasso painting - The Three Dancers, say. This is not experience as self-presence, but rather experience as self-rupture, a limitexperience. ${ }^{29}$ This practice deconstructs the Platonic origin of idealism, staging the limit of representation, but further, it reincorporates the limit into the (verbal) image, attempting to communicate it at a corporeal level of emotion. The affective violence of 'Rotten Sun' subverts the idealist subject by 'mythological' means that blur the distinction between objective language and subjective, irrational experience. (The term mythology itself bespeaks this ambiguity, in that it signifies both myth and its study.) Bataille's solar mythology circa 1930 overlaps with an unrealized bookproject about the castration complex, ${ }^{30}$ drawing on the contemporaneous culture of psychoanalysis, and mobilizing Freud's second topography. 'Rotten Sun' indicates an early, psychoanalytic phase in Bataille's method of meditation on images, in which the Romantic or Nietzschean artist functioned as a figure of identification. Narrator, reader, artist and viewer participate in a general economy of impossible specular identification with the blinding sun.

\section{The Platonic Unconscious}

\section{And Glaucon very ludicrously said, 'By Apollo, what a comble!'31 (Plato)}

Let us begin at the beginning, with the eye of idealism. The flip from ideal to actual sun typifies Documents' 'aggressively realist' or 'anti-idealist' thrust. ${ }^{32}$ The midday sun is an impossible percept. It can be apprehended only as a 'notion ... in the mind', a mental representation. This mental image has a 'poetic meaning' - it is a metaphor - of 'mathematical serenity and spiritual elevation': rational, changeless, transcendental. Its archetype is to be found in Books VI and VII of Plato's Republic, where, at the midpoint of the dialogue, Socrates presents the highest idea, the idea of the good, by means of the analogy of the sun.

Bataille's lexis of glare, blinding and fall subverts the Republic's rhetoric of light, sight and ascent. In Plato's account the light of the sun, productive of vision and life, equates to the power of the good to create truth and being (including that of its 'offspring', the sun). ${ }^{33}$ There is a strict correlation between visibility and intelligibility, an 'exact correspondence' between 'comprehending perceiving [noein], i.e. ultimately the perceiving of ideas', and 'sensory seeing. ${ }^{34}$ As the 'highest point' of Plato's philosophy, ${ }^{35}$ the idea tou agathou (idea or form of the good) authorizes the ocularcentric metaphysics of presence that Derrida had in mind when he wrote that the 'entire history of our philosophy is a photology, ${ }^{36}$ a discourse of light, by virtue of which, 'starting with its first words, metaphysics associates sight with knowledge. ${ }^{37}$ Idea and eidos (form) stem from idein, the verb to see. Theory itself (theoria: a looking at, viewing, contemplation, speculation, theory, also a sight, a spectacle) instantiates this visual regime. 
What Heidegger and Derrida termed 'metaphysics' is, in effect, what Bataille's 'anti-idealism' moves against. If idealism is philosophy that prioritizes ideas, then the Republic deals with the ideal idea of ideal ideas. The solar presentation of the idea tou agathou organizes the topography of the allegory of the cave, in the prisoner's upward trajectory from the cave of sensory becoming to the sunlight of true knowledge. Having been dragged up out of the cave, the prisoner is dazzled at first. Gradually his eyes become accustomed to the 'upper world', learning to see shadows, reflections, the night sky, until:

The thing he would be able to do last would be to look directly at the sun itself, and gaze at it without using reflections in water or any other medium, but as it is in itself. ${ }^{38}$

The visual apprehension of the highest idea is the ultimate step in the prisoner's 'ascent' to being. ${ }^{39}$ For Bataille the cave was a privileged locus of anti-mimesis, as the labyrinth was one of non-knowledge; but in 'Rotten Sun' Icarus's 'sudden fall of unprecedented violence', at the peak of elevation, undercuts the Platonic imagery of solar ascension. For Plato the solar idea tou agathou is the limit of philosophy, and for Bataille too - except that he inscribes paradox and violence at that limit, where the Republic does not.

Remarkably, faced with its own violence, in the light of its own negativity, Plato's solar metaphor of the good looks the other way:

In the world of knowledge, the essential form of good is the limit of our inquiries, and can barely be perceived [mogis horasthai], but when perceived, we cannot help concluding that it is in every case the source of all that is bright and beautiful - in the visible world giving birth to light and its master, and in the intellectual world dispensing, immediately and with full authority, truth and reason. ${ }^{40}$

The solar good is mogis horasthai, viewed only with difficulty, but it can be perceived, looked upon directly in the ultimate mode of vision that is true knowledge. In a recent commentary, the philosopher John Sallis has stressed that 'in the Republic no mention is made of the blindness that would result from looking upon the sun', ${ }^{41}$ despite Plato being explicit that 'looking upon the sun itself by itself corresponds to seeing the idea of the good. ${ }^{42}$ Sallis plausibly infers that the escaped prisoner, 'as we normally and regularly do', merely 'glances momentarily at the sun.' ${ }^{43}$ This may be, although Plato describes the prisoner's ultimate beholding of the sun as a direct looking, a gazing (katidein kai theasasthai) - what a standard French translation of Bataille's day rendered as fixer and contempler. ${ }^{44}$ (Bataille, it might be noted, uses the term fixer to describe viewing the blinding sun.) The authority of the good, an idea that is by definition perfect, palliates - idealizes, sublimates - the material negativity of the sensory sun. When ugliness, blindness, violence or bedazzlement appear in Plato's imagery of the idea tou agathou, they are always accidents of ignorance, rather than outcomes of the proper viewing of the solar good. ${ }^{45}$ 'Rotten Sun' stages the irruption of something like a Platonic unconscious, the unspoken aspect of the capstone of the Politeia, reincorporating into a heliopoetics the madness, violence, blindness, death - the evil - shut out by Plato's depiction. 


\section{Bataille's Pharmacy}

Qu'est-ce qu’une idée? C'est une image qui se peint dans ma cerveau. ${ }^{46}$ (Voltaire)

Bataille seems to be restoring literal or proper meaning to a sun 'emasculated' or neutralized by metaphor and the 'notion' or idea. Yet the blinding sun exceeds the oppositions literal/metaphoric, proper/figurative, material/ideal; undoes their ground and subject. By dint of excess it cannot be seen, known, submitted to discourse. It is the limit of idealism in the latter's condition of specularity:

Dazzlement is night at noon, the darkness that reigns at the heart of all that is excessive in the radiance of light. Dazzled reason opens its eyes to the sun and sees nothing, i.e. it does not see, for in dazzlement the general retreat of objects into the darkness has as its immediate correlative the suppression of vision itself. At the very instant when objects disappear into light's secret night, sight sees itself at the moment of its disappearance. ${ }^{47}$

Foucault was talking about Descartes, who 'closes his eyes' the 'better to see the true light of essential day, thereby ensuring that he will not suffer the dazzlement of the mad' ${ }^{48}$ But the metaphor of enlightenment extended a discourse of light whose origin, in the text of the West, was and is the Republic.

Jacques Derrida’s 1968 essay 'Plato's Pharmacy' glints on the horizon here, not least because it mimes what Bataille does to photology - to the Republic - in foregrounding the blindingness of the sun. Derrida stated that 'Plato's Pharmacy', with 'White Mythology' and others, was 'situated explicitly in relation to Bataille, and also explicitly propose[d] a reading of Bataille'.4 Though it is unclear whether Derrida had read 'Rotten Sun' in 1968, , $^{0}$ he knew the unpublished terminus of Bataille's 1930 solar mythology, 'The "Old Mole” and the Prefix Sur in Surhomme and Surrealism,', 51 which identified the idea with a castrative sun. ${ }^{52}$ 'Plato's Pharmacy' mentions Bataille once: regarding the historical 'champ de bataille' between Platonism and its enemies, Derrida announces that we are 'on the eve' (the originary limit) of Platonism (which is also the 'morning after Hegelianism'), when philosophy might be 'displaced into an entirely different field, where one can still, but that's all, "mime absolute knowledge," to use an expression coined by Bataille, whose name will enable us here to dispense with a whole network of references. ${ }^{53}$ The specific reference is to Inner Experience (1943), where Bataille entertains the 'final contradiction' that 'absolute knowledge is definitive non-knowledge': 54

There is in understanding a blind spot: which is reminiscent of the structure of the eye. In understanding, as in the eye, one can only reveal it with difficulty. But whereas the blind spot of the eye is inconsequential, the nature of understanding demands that the blind spot within it be more meaningful than understanding itself..$^{55}$

This notion of a meaningful blind spot in thought - 'Ultimate possibility. That non-knowledge still be knowledge. 56 - converges with 'Rotten Sun' and 'Plato's Pharmacy' at the limit of idealism. When Bataille writes of miming absolute knowledge it is Hegel he has in mind, but we should bear in mind that the Republic is also about absolute knowledge, the megiston mathema of the idea tou agathou. 
'Plato's Pharmacy' is best known as a reading of the Phaedrus, whence Derrida grabs the motif of the pharmakon of writing, oscillating ambivalently between poison and cure. But the argument turns on a blinding sun, refigured in a quasi-Oedipal scenario. It might be possible to reread 'Rotten Sun' in the light of 'Plato's Pharmacy', and vice versa. Something like an Oedipality is at play in 'Rotten Sun'; again, both texts issue from the crossroads between mythos and logos. To deconstruct the 'Platonic schema that assigns the origin and power of speech, precisely of logos, to the paternal position', ${ }^{57}$ Derrida rereads the origin-story by which Theuth (the Egyptian god Thoth) presents the invention of writing to the sun-king Thamus (Ammon-Ra). Derrida uses mythography to parse Ammon-Ra as a Father who creates with the spoken Word: 'a hidden sun, the father of all things, letting himself be represented by speech' ${ }^{58}$ Then, in a rapid traversal, he identifies this paternal, solar position with the good of the Republic.

Notwithstanding some ambiguity, the Republic does present the good as a father to the sun, pater to its ekgonos (male offspring). ${ }^{59}$ Plato also plays on tokos, which signifies both 'child' and 'interest on a capital investment', when he says that he will not speak directly of the good, but will offer the analogy of the sun as its tokos. ${ }^{60}$ For Derrida, this paternal function requires the good to be blinding: 'the good (father, sun, capital)' becomes the 'hidden illuminating, blinding source of logos'. Philosophy has recourse to reason 'from fear of being blinded by any direct intuition of the face of the father, of good, of capital, of the origin of being in itself, of the form of forms, etc. ${ }^{61}$ But as we have seen, the Republic disavows the blinding aspect of the solar analogy. In order to recode the good as blinding, Derrida must insert a discussion of the physical sun taken from the different context of the Phaedo. ${ }^{62}$ Making of the good a blinding father requires heuristic violence or anatopism, against scholarly decorum.

The ecstatic and deliberately non-logical conclusion to 'Plato's Pharmacy' superimposes this recoded motif of the blinding origin onto Plato's claim that although the good is the origin of being, it is at the same time beyond it (epekeina tes ousias): ${ }^{63}$

The absolute invisibility of the origin of the visible, of the good-sun-fathercapital, the unattainment of presence or beingness in any form, the whole surplus Plato calls epekeina tes ousias (beyond beingness or presence), gives rise to a structure of replacements such that all presences will be supplements substituted for the absent origin .... To repeat: the disappearance of the goodfather-capital-sun is thus the precondition of discourse, taken this time as a moment and not as a principle of generalised writing. That writing (is) epekeina tes ousias. The disappearance of truth as presence, the withdrawal of the present origin of presence, is the condition of all (manifestation of) truth. Nontruth is the truth. Nonpresence is presence. ... Death rehearsal. Unreserved spending. ${ }^{64}$

To repeat: the good in the Republic is not absolutely invisible. Again, disappearance and withdrawal (retrait) are not the same.$^{65}$ But the revision is effective: the good, the origin of truth, knowledge, being, insofar as it is epekeina tes ousias, becomes pharmakon, différance - and blinding. Like 'Rotten Sun', the final throes of 'Plato's Pharmacy' perform contradiction ('nontruth is the truth'), as origin merges with simulacrum to mime absolute knowledge in a death-driven general economy. The beyondness of the epekeina tes ousias coincides with its prohibitive blindingness. The transgression of the prohibition by which the paternal good founds reason becomes an ecstatic or sacrificial experience of contradiction. 
Derrida's insertion of the Phaedo into the Republic recalls Bataille's exposure of the blinding sun, in reinstalling what Plato's solar good displaces: visible blindness, the paradox at the limit of an idealism that is by definition ocularcentric. In 'Antivision', her manifesto-like contribution to a 1986 special Bataille number of October, Rosalind Krauss invoked ‘Rotten Sun’:

Representation is born, then, at the limit: where light turns to darkness, where life surrenders an image of death, where sight is extinguished in a revelatory moment which is the same as blindness. ${ }^{66}$

This paradox at the limit of thought is quite traditional. For Hans Blumenberg, the 'coincidence of seeing and not-seeing' in the 'absolutely dazzling' was the 'fundamental confirming experience of all mysticism, in which the presence of the absolute attests itself, in which all thinking and speaking is surpassed'. Nicholas of Cusa expressed his 'learned ignorance' of a God defined as the coincidence of opposites, in the motif of visible blindness. ${ }^{67}$ Excaecatio, wrote Bonaventure, est summa illuminatio: blindness is the highest illumination. ${ }^{68}$

These motifs enunciate the Platonist or Neoplatonist tradition of negative theology, which at times Bataille and Derrida both negotiated. ${ }^{69}$ (Bataille's reading of Plato in the 1920s seems to have been marked by his relationship with the Russian existentialist philosopher and 'mystic', Léon Chestov, ${ }^{70}$ whose critique of rational discourse - made through Dostoyevsky and Nietzsche - as always eventually stumbling 'on the irrational of human thought', ${ }^{11}$ was an important if often forgotten factor in the interwar Parisian intellectual scene. $)^{72}$ When Derrida addressed the epekeina tes ousias as a founding trope of apophaticism, he argued that Plato's beyond (epekeina) was not simply negative, but a 'hyperbolism' that 'first of all obeys a logic of the sur, of the hyper, over and beyond'. ${ }^{73}$ In other words, this 'transgression through excess $^{74}$ of the good follows the pattern of those 'Icarian' (Icarus-like) ventures - utopian-socialist, Bretonian-surrealist, Nietzschean - against which Bataille famously counterposed the Marxian, proletarian 'old mole'.75 As Hollier has acknowledged, prior to the 'Old Mole' article - itself exceptional and unpublished - Bataille had never given Icarus a negative inflection. ${ }^{76}$ Rather, he had valorized crossing the limit of being as a masochistic experience of sacrifice, fall or castration. 'Rotten Sun' stages an Icarian transgression that, in the terms of the 'Old Mole' piece, veers close to surrealism. It is worth noting that at the end of 'Plato's Pharmacy' Derrida also seems to valorize the blinding experience of the epekeina tes ousias, associating it with death and dépense.

Derrida was circumspect about Bataille's relation to negative theology; ultimately the point is that there is no God in this atheology, no supreme telos. ${ }^{77}$ The proximity of Bataille's thinking to mysticism is like its proximity to, yet difference from, the Hegelian Aufhebung, that bête noire of post-structuralism: 'far from suppressing the dialectical synthesis', Bataillean sovereignty 'inscribes this synthesis and makes it function within the sacrifice of meaning. ${ }^{78}$ I'll return to the question of Bataille's complicity with sacrificial thinking, what Jean-Luc Nancy has called trans-appropriation - a neologism that incorporates metaphor and sublation. In 'Rotten Sun', the problem of the beyond would seem utterly material: the limit is the insuperable one of blinding. Nonetheless, this sensible sun does seem to access a 'beyond', insofar as what Bataille called the heterogeneous might be considered 'beyond' the homogeneous. Madness, waste, ejaculation, ecstasy, sacrifice: this is indeed the excluded province of the heterogeneous, as described in the unpublished essay from circa 1930, 'The Use 
Value of D.A.F. de Sade', where Bataille positioned systematic thought as a restricted economy:

... the intellectual process automatically limits itself by producing of its own accord its own waste products, thus liberating in a disordered way the heterogeneous excremental element. Heterology is restricted to taking up again, consciously and resolutely, this terminal process which up until now has been seen as the abortion and the shame of human thought.79

It is Platonism's terminal - or originary - process that 'Rotten Sun' takes up.

\section{The Sacrifice of Metaphor}

Soleil cou coupée ${ }^{80}$ (Apollinaire)

Bataille's exposure of the physical sun before the metaphysical (and metaphysics means post-physics) mimics the procedures of nineteenth-century mythography. Max Müller and a host of imitators expended much ink in revealing the physical sun as the true referent of Indo-European mythology. ${ }^{81}$ Anatole France's 1895 mockPlatonic dialogue, The Garden of Epicurus, addressed the language of metaphysics, the 'white mythology' of the West, in similar terms, inquiring into the 'primitive and concrete meaning that lurks yet present under the abstract'. ${ }^{82}$ In the 1971 text which takes its title from Anatole France, 'White Mythology: Metaphor in the Text of Philosophy', Jacques Derrida located The Garden of Epicurus in a broad nineteenth- and early twentieth-century configuration of interest in 'the metaphorical sedimentation of concepts'. ${ }^{83}$ We must add Bataille to this configuration, and indeed, although Bataille is a silent interlocutor, Derrida's penultimate footnote cites 'Rotten Sun'. ${ }^{84}$ 'Above all', Derrida writes apropos of Hegel, 'the movement of metaphorisation (origin and then erasure of the metaphor, transition from the proper sensory meaning to the proper spiritual meaning by means of the detour of figures) is nothing other than a movement of idealisation. ${ }^{85}$ This process of metaphorization is at stake in 'Rotten Sun'.

At some point in this process, the blinding materiality drops out of Plato's analogy. 'Rotten Sun' stages this material surplus or remainder. Documents has been associated with 'an irreducible kernel of resistance to transposition, to substitution, a reality intractably resistant to metaphor' ${ }^{86}$ 'Rotten Sun' would seem to participate in this drive. Hollier identifies the resistance to transposition with resistance to monetary exchange, and in fact Bataille does inscribe an incipient economics of metaphorization in 'Rotten Sun'. Whereas Plato's solar analogy is a contract that profits the listener or reader in line with the laws of economic exchange, ${ }^{87}$ Bataille's blinding sun generates a general economy in looking or understanding. To focus on the blinding sun 'implies a certain madness' or psychical excess. Whereas the economy of dematerialization that yields the intelligible sun is one of 'production', the blinding sun changes the 'meaning' of the 'notion' because bedazzlement 'appears in the light' as 'waste'. Appearance, the liminal percept, combusts; sun meets eye, mind, mind's I, scorching the mental image or idea along with the retina. Catastrophic co-presence of the idea with the real thing.

A particular idealization is at stake in the blinding image of the "blazing arclamp'. In Surrealism and Painting (1928) André Breton had portrayed Picasso as a hero 'advancing deep into unknown territory, his hands full of rays' (ses mains pleines de 
rayons), a 'powerful searchlight' (puissant projecteur) penetrating the obscurity of the unconscious: light of the underworld, redemptive illuminatus, effulgence qua epistemological conquest. With Bataille's arc lamp the puissant projecteur turns on the viewer, no longer lighting the way like a benign lamp of inspiration, but blinding with totalitarian sadism - with the violence of a border guard. The Three Dancers that accompanied 'Rotten Sun' had appeared in the same number of La Révolution surréaliste as the phosphorescent Picasso of Le Surréalisme et la peinture, annexed to Breton's theorization of the surrealist oeuvre plastique. The latter, Breton said, in order 'to respond to the necessity of absolute revision of real values on which today all minds agree, will therefore refer to a purely interior model, or will not be. ${ }^{88}$ It was a straightforwardly idealist proposition: only a mental image could change reality. Bataille responded by rupturing this conventional teleology at source: 'when Picasso paints', he wrote, 'the idea ... aborts'. ${ }^{89}$ This originary limit is on show in 'Rotten Sun', in the impossible images of the blinding sun and lamp.

The concept of metaphor as 'transposition' goes back to Aristotle's definition in the Poetics, which stressed the movement of epiphora. ${ }^{90}$ Aristotle also grounded metaphor in visual resemblance, homoiosis: 'to metaphorise well is to see a resemblance [to to homoion theorein]. ${ }^{91}$ Contemporary semiotics still designates metaphor an iconic sign. ${ }^{92}$ Yve-Alain Bois has been vociferous in his expulsion of metaphor, figure and resemblance from the problematic of the informe..$^{93}$ Thus he has rebutted Georges DidiHuberman's claim that Bataille's Documents texts perform a 'theoretical dismantling' of the 'classical notion of resemblance.9 ' 'Rotten Sun', however, does read as a rupture in the regime of homoiosis, adaequatio, representation or 'correctness of vision' - the regime, that is, of metaphysics, whose historical retreat from truth as aletheia, unveiling, Heidegger tracked from Plato onwards. ${ }^{95}$ (To be sure, Didi-Huberman's insistence on the déchirure or transgression of a resemblance qualified as Thomist seems apt in this respect.) If resemblance signifies iconicity, 'Rotten Sun' inscribes the paradox at its limit. And yet, rather than expel figure, 'Rotten Sun' reinscribes this limit in the figural order. ${ }^{96}$

The text attacks the rational Subject on two fronts: with the unknowable sun, and with horrific images. Notwithstanding the classical impossibility of a metaphor for the destruction of homoiosis, the horrific images bear a relation to the blinding sun broadly consistent with the analytic paradigm of metaphor expressed in the subjectpredicate form, S is P (Searle's example is, 'Juliet is the sun'). ${ }^{97}$ Thus, in an anguished process which Didi-Huberman describes as the setting in motion [mise en mouvement] of the informe', the blinding sun 'is' foam on the lips, the epileptic crisis, Mithras killing the bull, and so on. ${ }^{98}$ These blinding, paroxysmal or wounded 'figures' image the violence of reincorporating the blinding image into the figurative order. They also elicit affects in the reader.

'Rotten Sun' destabilizes the normative, 'objective' distinction between text and reality. The connection between sun and lamp is symptomatic here. The blinding sun's combustion of the idea - the impossible excess where the blinding visual image meets the blinded mental image - is 'expressed, psychologically, by the horror radiating from a blazing arc-lamp'. Bataille's elusive syntax means that the arc lamp does not correspond to the blinding sun as a metaphorical equivalence. Rather, the horror it radiates is the psychological expression of the experience of solar blinding. The arc lamp does not represent the blinding sun so much as enact it, not by producing light, but by radiating affect, as the difference between observing subject and blinding object collapses. The blinded observer merges with the observed sun and arc lamp in a zone of horrific pathos or identification. 
This points to the way imagery operates in 'Rotten Sun'. Bataille mimes the objectivity of the psychologist - 'in practice the scrutinised sun can be identified' - and immediately subverts it, with 'mental ejaculation, foam on the lips, and the epileptic crisis'. The blinding sun is identified - a key term, along with expression, for the relation between the blinding sun and its avatars - with the very transgression of identity. The strange non-image or anti-idea of a 'mental ejaculation' suggests the mind throwing itself out of itself with a cry or an expulsion of sexual fluid: ekstasis - the mind beside itself - as jouissance. 'Foam on the lips' is an image whose dissonance, befouling the organ of speech, exceeds its function as a medical symptom. Elsewhere Bataille likened 'foam on the lips' to his 'excessive' need to transgress the 'limits of our human experience'.99 One recalls the proximity in Dostoyevsky between the grand mal or falling sickness, and the sacred - Prince Myshkin's ecstasy, the 'flash of light' in the 'unendurable' second before the fit. ${ }^{100}$

Although 'Rotten Sun' would seem to pre-empt the medical literature, over the course of the twentieth century psychiatry did develop a diagnosis of photogenic or heliotropic epilepsy. ${ }^{101}$ Similarly, in his other contemporaneous writings Bataille mixes psychiatric material with his own solar mythology, so that it becomes difficult to disentangle the objective from the subjective. Amy Hollywood has read this tendency as a device for eliciting inner experience in the reader, claiming that:

... the key to his use of objective, scientific language lies here - it is not that he wishes to make his subjective experience objective, but that he wants to move the reader from the language of science to that of experience. Precisely the contradictions in his use of scientific language (and the contradiction between scientific and existential language) work to engender inner experience (and hence, paradoxically, to render Bataille’s writing general). ${ }^{102}$

The movement from scientific language to experience takes place in the ascription of affect to the arc lamp. The images of 'mental ejaculation' and 'foam on the lips' unsettle, dislocate the reader as much as they grant information. A desire is at play, to make the reader feel what the text describes.

The shift from scientific language to emotive image is operative in the most memorable scene of 'Rotten Sun'. Having told us that the blinding sun is 'horribly ugly' by contrast with the Platonic perfection of the ideal sun, Bataille states that the viewed sun 'is identified' mythologically - the passive verb again mimicking an objective order of knowledge - with Mithras and Prometheus. Claiming that the 'Mithraic cult of the sun led to a very widespread religious practice', Bataille then provokes horror in the reader with an image of sacrifice; horror tending to ambivalence, as he insists on the moral 'benefits' of the 'lovely shower' of blood. The Mithraic genealogy of this type of bull-sacrifice is disputed today. In Mithraic temples the god Mithras is indeed depicted sacrificing a bull; yet the gruesome taurobolium pertained not to the secret rites of Mithraism, but to the public cult of the Magna Mater. ${ }^{103}$ Early twentieth-century scholarship did link Mithraism to the taurobolium, ${ }^{104}$ but the dominant interpretation of the former was as a solar religion that prefigured, paralleled and was superseded by Christianity. Rather than the enlightened 'morality of Mithraism' that dominated these accounts, ${ }^{105}$ Bataille foregrounds horror and sacrificial violence.

Of the Bataillean relation between art and sacrifice, Jean-Luc Nancy has written that for Bataille, art 
$\ldots$ is limited to the simulacral, and at the same time it matters only through the cruelty, the horror that it brings out, and which (so to speak) means something - in any case, only has force - if it is not simulated ....: it involves, whatever the detours, acceding - even if only a little - to the effective exercise of an effective cruelty, at least in its emotion. ${ }^{106}$

Nancy locates sacrifice at the foundation of the Subject of Western idealism. Starting with Socrates and Christ, the 'old' sacrifice was interiorized and spiritualized into dialectical reason or what Nancy calls 'trans-appropriation'. However, at the 'bloody heart' of the latter, the horror of sacrifice casts an 'obscure light' - on which Bataille fixed his eye:

But what, exactly, does the eye see? It sees its own sacrifice. It sees that it cannot see except on the condition of an unbearable, intolerable vision - a vision of sacrificial cruelty. ${ }^{107}$

'Rotten Sun' dramatizes this double condition: the blinding sun is the material, affective and sacrificial remainder of a cosmological (Platonic and Christian) idealization, sublation or metaphorization. For Nancy, fascination with the bloody cruelty of sacrifice risks complicity with appropriative reason. How can Bataille think sacrifice, he asks, 'without having fascination constitute itself as mastery and dialectical knowledge'? In fact, Nancy writes,

Everything occurs as if the spiritualisation/dialect[ic]isation of sacrifice could not operate without a formidable disavowal of itself. It disavows itself beneath the figure of an 'old' sacrifice, which it pretends to know and which in reality it fabricates for its own purposes. ${ }^{108}$

This is the image of the taurobolium.

Nancy calls for an end to sacrificial thinking. There is, he states, no 'outside' of finitude to be transgressed. ${ }^{109}$ Yet Bataille thought in these terms. In 1930, he sought the outside of dialectical knowledge in a sacrificial cruelty continuous with unconscious drives. 'Rotten Sun' ascribed importance to the human attitude to the sun because 'the drive of the psychological movements described has not been diverted and attenuated by secondary elements.' Around this time, psychoanalysis offered Bataille a materialism of the drives, a somatic theorization of mind, ${ }^{110}$ and he looked to avant-garde painting to open the way to 'the expression (by the same token to the exaltation) of the psychological processes most incompatible with social stability'. ${ }^{111}$ Only at the end of Documents did he abjure this possibility. ${ }^{112}$

I would contend that a certain practice of anti-idealist spectatorship informs Bataille's art writing in Documents. Later, on the eve of the 1939-45 war, Bataille developed the method of meditation on death by which he evoked inner experiencewhich was by no means experience as phenomenological self-presence, but rather a groundless ecstasy, a shattering of self. ${ }^{113}$ Peter Tracey Connor has stressed the crucial experience of 'those perfect contraries, divine ecstasy and its opposite, extreme horror', which Bataille underwent in 1938, in gazing upon the photograph, which he claimed was given to him in the mid-1920s by his psychoanalyst Adrien Borel, of the 1905 dismemberment of the Chinese criminal, Fou-Tchou-Li. ${ }^{114}$ Fascinated by the victim 'his hair standing on end, hideous, haggard, striped with blood, beautiful as a wasp' 


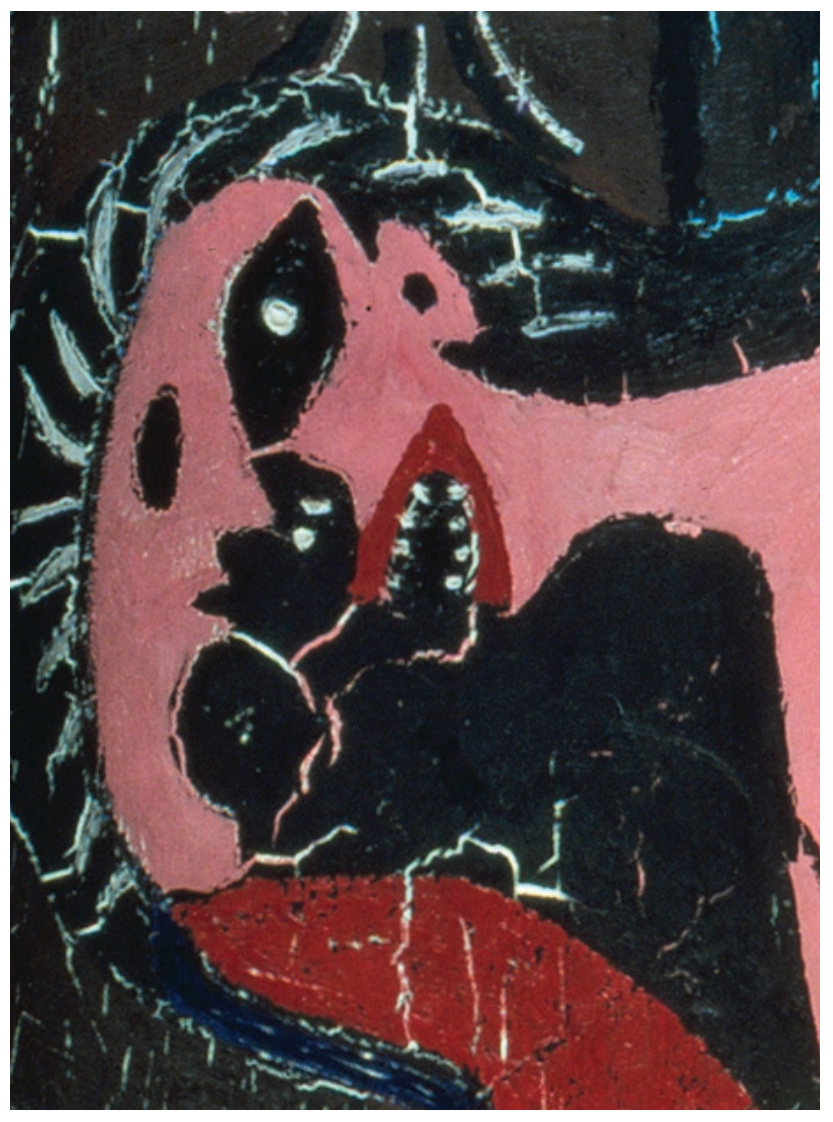

- Bataille interjects: 'I write "beautiful”! ... something escapes me, flees from me, fear robs me of myself and, as if I had wanted to stare at the sun, my eyes rebel. ${ }^{115}$

I want to connect this practice of looking to induce 'a dramatic loss of self', with Bataille's approach to images in Documents. ${ }^{116}$ The contexts are different, to be sure, with 'mythology' and psychoanalysis playing the role in 1930 that medieval mysticism and Nietzsche would a decade later. It does seem, however, that Bataille had begun to practice something akin to his later method of meditation by the early $1920 \mathrm{~s} ;{ }^{117}$ and it is not insignificant that he first uses the phrase expérience intérieure (to my knowledge) in the Documents article 'Sacrificial Mutilation and the Severed Ear of Vincent Van Gogh', where sacrifice 'implies a drive [impulsion] revealed by an inner experience', of which 'the selfmutilation of madmen is only the most absurd and terrible example'. ${ }^{118}$ This drive is to perform an 'act of looking the sun in the face' that is 'equivalent to identification'119 - an impossible, rupturing identification with the limit of thought.

Bataille was explicit that looking at a painting could do this:
2 Detail of Pablo Picasso, The Three Dancers, 1925.
If the forms brought together by a painter on a canvas had no repercussion, if for example, since we are speaking of voracity - even in the intellectual order -, if horrible shadows that collide in the head, if jaws with hideous teeth had not come out of Picasso's skull to terrify those who still have the effrontery to think honestly, then painting at the very most would be good for distracting people from their rage, in the same way as bars or American films. But why hesitate to write that when Picasso paints, the dislocation of forms leads to that of thought, that is to say that the immediate intellectual movement, which in other cases leads to the idea, aborts. ${ }^{120}$

On the one hand, anti-idealist painting undoes the subject of honest thought by psychical terrorism, imaging phobic fantasy, as the cannibalistic jaws exit Picasso's mind like an anti-Athena. On the other, Bataille inscribes abortion in the generation of the idea, in the formation of thought as representation or image. He imagines a prior moment in the idea's origination, the 'immediate intellectual movement' before (or during) its differentiation, in which he installs death or dislocation - a prior rupture in the traditional idealist sequence of artistic creation whereby the artist has an idea and then translates it to the artwork. ${ }^{121}$ This is the rupture Picasso installs in the picture, at the originary limit of the idea.

We can see these operations in The Three Dancers. What Bataille elsewhere called the 'affective violence' of 'mythological phantasms'122 is at play, for example, in the left-hand dancer - who indeed possesses ‘jaws with hideous teeth' (plate 2). An aggregate of anxious nineteenth-century masculinist stereotypes, she embodies ekstasis, unreason, castration, and the co-presence of sexuality with death. She arches in Bacchante posture; her head jerks horizontal, broken, emptied out, eyes and nose 
3 Detail of Pablo Picasso, The Three Dancers, 1925.

4 Detail of Pablo Picasso, The Three Dancers, 1925 [rotated 90 degrees anticlockwise].
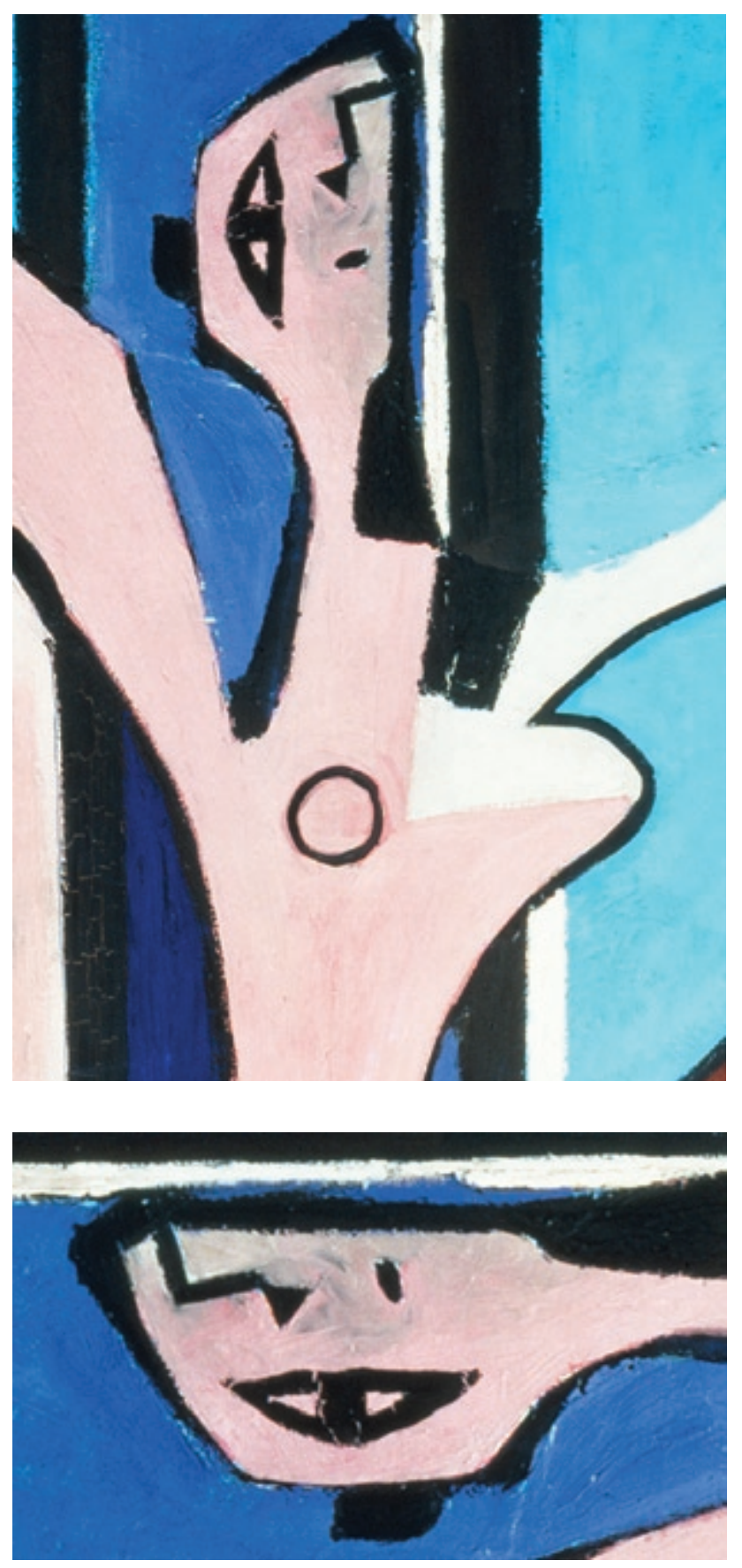

pure shade except for the gleam of a spectral snout and a single negative pupil. In the forehead, a third eye - the second sight? But completely dark. This hole plays the eye to another, sickle face - a trope of lunacy consistent with the traditional contract, honoured by Baudelaire, between the feminine and the moon. ${ }^{123}$ (Yet there, in the middle of the Bacchante's tambourine-shaped hoop-la of an arm: the sun.) A disintegrating death's head, demonically animated, anti-rational, crowned with the sparse white hair and black cowl of the crone; and yet the topmost breasts are full and high, their swollen nipples flung up by the undulation of the jive. Two other breasts send this dark Diana jigging towards Ephesus. She is mortuary yet fecund, on the hoary womb lip. At her groin a simple cut-out in a flapper's skirt, a stand-in absence offset by the railing that fetishizes the imagined slit. Consider that horizontal half-mandorla mouth - a cunt spread, lipsticked, tricked out with fangs into a textbook vagina dentata. The castrated, castrating madwoman: phallogocentric horror cliché, from Euripides to surrealism. For Bataille's bourgeois, masculine, homogeneous subject, to meditate upon this figure might be to identify with something heterogeneous.

To move from the left-hand to the central dancer is to move from the iconography of Dionysus to that of the Crucified (likewise feminized); but simultaneous with these depictions of ecstasy and torture is Bataille's other anti-idealist mode: the mobilization of contradiction or excess in the visual image - that is, in perception. Gestalt-switches flicker in the sky around the dancers (see plate 1): a profile at top left; another, inverted profile answering the black one of the right-hand dancer; a mouth, perhaps, at the black nipple of the Bacchante. Visual ambiguity runs riot: the Bacchante's hole; her eye-breast; her serrated flap of thigh like many mouths. The white hand of the right-hand dancer as a monster's head, sucking at the Bacchante's hand. Every dancer has at least two faces. The central breast, like an 'O!', a zero or a circle pointed out by that white arrow of a shoulder, like a mouth in her chest.

And in the central dancer's mouths the two modes, of iconic affect and iconic defect or excess, coincide. The first perceptible mouth is small and prim, its affect repressed, beneath the schematic brow and nose, beside the sideways eye (plate 3). As David Batchelor has pointed out, that eye, should one tilt one's head to horizontal, becomes a gaptoothed, grinning mouth, the prim lips an eye, the brow another brow. (plate 4) ${ }^{124}$ The tortured woman, mock-Christ, turns crudely-laughing bearded lady. I see a third mouth, too, at the jagging collar-bone of the first face. If we ignore the prim mouth, and instead interpret that collar-bone as the lowerjaw of a gaping scream, then the head as a whole 
incorporates the spectrum of emotion, from horror to laughter - affects within touching distance for Bataille. Ambiguity generates a term of some importance to the latter: ambivalence. In fact his uses of it are among the first in the French lexicon. Dictionaries give the first usage of ambivalence as 1936 or 1937; the Grand Robert cites André Breton's L'Amour fou as its first example. ${ }^{125}$ Yet translations of Freud disseminated the term in the 1920s. Around the time of 'Rotten Sun', Bataille used it to describe the operation of excretion and the heterogeneous. ${ }^{126}$ And in a document related to his own psychoanalysis with Adrien Borel, he referred to a 'kind of ambivalence between the most horrible and the most magnificent' elicited by a seduction fantasy about a sadistic father: 'I'm something like three years old my legs naked on my father's knees and my penis bloody like the sun. ${ }^{127}$

\section{The Prodigal Father}

My father slaps me and I see the sun. ${ }^{128}$ (Bataille)

The Dictionnaire critique entry for 'Sun', written by the Serbian avant-gardist, member of the Grand Jeu and future contributor to Le Surréalisme au service de la révolution, Zdenko Reich, describes, in Frazerian, folkloristic mode, an early nineteenth-century 'solar cult' in a village in the Hautes Alpes ('the whole ceremony pivots about the ritual of the omelette. Laid on the parapets of the bridge, being the image of the sun, it attracts its likeness while the inhabitants dance in the nearby meadow'). ${ }^{129}$ In 'Rotten Sun', Bataille employs the language of a mythologist, in particular the term identification as the mode of relation between the sun and its proxies. This mythological anthropology is inseparable from the contemporaneous culture of psychoanalysis. Freud himself, albeit under the aegis of reason, had taken the audacious step of inventing the 'scientific myth of the father of the primal horde' in Totem and Taboo. ${ }^{130}$ While myth may be so elusive as to be an 'untraceable genus,', 131 with 'no satisfactory theory,'132 Jean-Luc Nancy, in a penetrating analysis, has argued its 'principial' function: 'All myths are primal scenes, all primal scenes are myths. ${ }^{133}$ Elsewhere, discussing the Republic's proscription of bad myths, Nancy and Philippe LacoueLabarthe have argued that 'myth, like the work of art that exploits it, is an instrument of identification. It is, in fact, the mimetic instrument par excellence. ${ }^{134}$ With the sun comes origin, of myth, metaphor, knowledge, being. 'Rotten Sun' turns on an identification with this origin.

At the time of 'Rotten Sun' Bataille entertained the possibility of a 'mythological anthropology' that would introduce a 'lawless intellectual series into the interior world of legitimate thought'. ${ }^{135}$ The strict 'exclusion of mythology by reason' answers the 'affective violence' of 'mythological phantasms', but 'it is necessary to overturn the values created by means of this exclusion; in other words, the fact that reason denies any valid content in a mythological series is the condition of its significant value. ${ }^{136}$ In this way, 'Rotten Sun' introduces a series of transgressive 'mythological' images into the privileged figural order of idealism: an idiosyncratic 'Mithras' letting bull's-blood; Prometheus eviscerated by the 'vulture' or eagle; 'a man slashing his own throat'; an 'anthropomorphic being deprived of a head'; Icarus at the moment of fall. I would attach Picasso to this list of identifications, as elsewhere Bataille linked Van Gogh to Prometheus. ${ }^{137}$

Bataille's mythological anthropology recapitulates the traditional dualism by which mythos - which originally meant simply 'speech' or 'word' - has been opposed and subordinated to logos. ${ }^{138}$ Bataille seems to have thought of the psyche as 
structured by solar myth; for him the 'psychological entity' of Icarus indexed 'the role of the sun in human impulses. ${ }^{139}$ Yet Bataille's solar mythology bears a modern burden. Posing the sun as the origin of myth and sacrifice, Bataille refigures a central obsession of nineteenth-century mythography. Gillian Beer has convincingly linked the mythographic fixation on the sun as the primordial referent of myth, to "covert dreads' about the death of the sun, prompted by the theories of Victorian solar science. ${ }^{140}$ From Max Müller through to J. G. Frazer (by way of Judge Schreber), anxiety about solar death subtended the mythographic imagination. The discovery of radioactivity at the turn of the century did not erase the figure of the dying sun; in the Theory of Religion Bataille would write that 'sacrifice burns like the sun that slowly dies of the prodigious radiation whose brilliance our eyes cannot bear.' ${ }^{141}$ A death drive is active in 'Rotten Sun', too.

I think Freud's second topography, which had been published in French translation in 1927, inflects Bataille's rhetoric of dualism, idealization and violence, so that the two suns register the two sides of the ego ideal or superego hypothesized in The Ego and the Id. ${ }^{142}$ Superego: on the one hand the ideal origin of all religion and authority, answering 'to everything that is expected of the higher nature of man'; ${ }^{143}$ on the other the crony of the id, ${ }^{144}$ an instrument of death, implacably, irrationally cruel. Identification with the ideal father requires a sublimation of libido, diverting the binding force of Eros to the ego. No longer fused, the death instinct is unleashed in the superego's name. ${ }^{145}$ This is an economics of idealization or sublimation.

(Let us not forget that sublimation has been used on occasion to translate Aufhebung.) $)^{146}$ The restricted economy of idealization excretes an excess that attacks the ego with cruelty and death:

In suffering under the attacks of the superego or perhaps even succumbing to them, the ego is meeting with a fate like that of the protista which are destroyed by the products of decomposition that they themselves have created. From the economic point of view the morality that functions in the super-ego seems to be a similar product of decomposition. ${ }^{147}$

Compare the rotten sun: 'it is no longer production that appears in light, but waste'; Picasso's painting performs a 'decomposition of forms'; the blinding sun 'can be identified' with 'the epileptic crisis'. In The Ego and the Id Freud suspected that 'the epileptic fit is a product and indication of an instinctual defusion', of the death drive rampant. ${ }^{148}$

About Van Gogh, Bataille was clear: the 'double bond uniting the sun-star, the sun-flower, and Van Gogh' can ‘be reduced to a normal psychological theme in which the star is opposed to the withered flower, as are the ideal term and the real term of the ego.'.49 Van Gogh's self-mutilation expressed an 'intention to resemble perfectly an ideal term, characterised quite generally in mythology by a solar god tearing and ripping off his own private parts [ses propres parties]. ${ }^{150}$ The Freudian superego imprisons the ego in a double-bind: "'You ought to be like this (like your father)"'; '“You may not be like this (like your father)"'.151 The 'superior being' enforces the limit of identification by the threat of castration. ${ }^{152}$ To become the ideal, to cross the limit, was to undergo castration.

For Bataille in 1930, such an inner experience would be an heroic masochism. The 'legend of Prometheus' pertained to the 'complex of castration', a 'tragicomic, incontestably ridiculous' yet 'essential human adventure': 
... it would be possible to determine, in the course of every castration complex, a solar point, a luminous, almost blinding bedazzlement that has no other outcome than in the blood of cut flesh and in the nauseating swaying at the moment when the face becomes deathly pale ... The child who, in his terror of being cut, seeks to provoke the bloody resolution, in no way displays an absence of virility: on the contrary, an excess of strength and a crisis of horror project him towards whatever in the world is the most cutting, that is to say the solar glare [l'éclat solaire]. ${ }^{153}$

To cross the limit is to undergo castration; not to do so is to remain subordinate. This is a Freudian riff on the Nietzschean Prometheus, who looks with 'fearless Oedipus-eyes': ${ }^{154}$ 'In the individual's heroic effort to achieve universality, in the attempt to escape the spell of individuation, to become the only being in the world, he encounters the hidden primal contradiction - he commits sacrilege, that is, and he suffers. ${ }^{155}$

For Bataille the 'irresistible wish to become a sun oneself (a blinded or blinding sun, it matters little)' manifested itself in an 'act of looking the sun in the face' that is 'equivalent to identification. ${ }^{156}$ Picasso's painting, he tells us, participates in the mythological practice of the sun. To look upon Picasso's painting of the late 1920s is to undergo the lacerating experience of the limit. But further, it is to identify with the artist, to see with his 'fearless Oedipus-eyes'. Does a structure of identification not underpin the myth of expression? In the context of the Hommage, are we not meant to understand Picasso as the 'Soleil pourri'? The Romantic mythology of genius was a solar one. In the third Critique Kant concatenated God, King, Sun, Poet, Genius, by giving as his example of poetic genius - in Derrida's words, the 'generous overabundance of a solar source' - a verse about the sun, penned by Frederick the Great. ${ }^{157}$ For Bataille's generation Picasso was a self-transgressing patriarch, a prodigal father - even a sadistic father. ${ }^{158}$ The sovereign experience could be accessed through his painting. And yet - this sovereignty is predicated on an exception.

Bataille's heroes - Picasso, Van Gogh, later Nietzsche and Rimbaud - were all geniuses of the cult-of-genius sort. Picasso's sovereignty according to Bataille may have been self-shattering, but it was also aristocratic.

Impossible metaphor, impossible identification, impossible sublation: these are the scissions of 'Rotten Sun'. It takes the fabric of discourse - academic discourse, the discourse of this article - and tears it, not for Eros, but for the death drive. It is implicated in outmoded myths. And yet, though this is not creative writing, it is not (only) destructive. Rather, it affirms the operation of the 'lawless intellectual series' in 'legitimate thought'. It affirms the experience of the limits of knowledge.

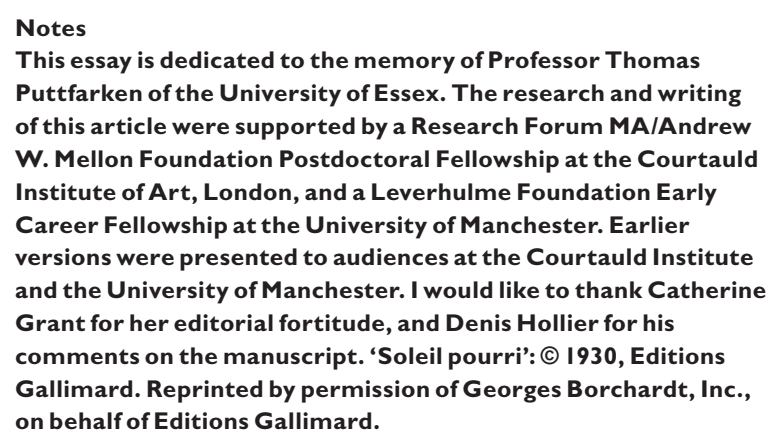

Notes

This essay is dedicated to the memory of Professor Thomas Une University of Essex. The research and writing W. Mellon Foundation Postdoctoral Fellowship at the Courtauld Institute of Art, London, and a Leverhulme Foundation Early Career Fellowship at the University of Manchester. Earlier versions were presented to audiences at the Courtauld Institute and the University of Manchester. I would like to thank Catherine Grant for her editorial fortitude, and Denis Hollier for his Gallimard. Reprinted by permission of Georges Borchardt, Inc. on behalf of Editions Gallimard.
1 'Au fond, tout ne tient qu'à soi. C'est un soleil dans le ventre aux mille rayons. Le reste n'est rien.' Pablo Picasso, quoted in Eugène Tériade, 'En causant avec Picasso', L’Intransigeant, 15 June 1932.

2 Guillaume Apollinaire, 'Zone', Alcools, Paris, 1913, 7-17, 17.

3 The name on Apollinaire's birth certificate was Guglielmo Alberto Wladimiro Apollinare de Kostrowitzky. See Pierre-Marcel Adéma, Guillaume Apollinaire, Vienne, 1968, 9-10. In ‘Que vlo-ve?' he calls on Apollo as his 'Patron'. See Guillaume Apollinaire, Oeuvres complètes I, Paris, 1965-6, 166. He once stated simply: 'je suis solaire'. See Louise Faure-Favier, Souvenirs sur Apollinaire, Paris, 1945, 118. On Apollinaire and the sun see David Berry, 'Apollinaire's solar imagery', in Roger Cardinal, ed., Sensibility and Creation: Studies in Twentieth-Century French Poetry, London and New York, 1977, 36-56. 
4 Guillaume Apollinaire, 'Young artists: Picasso the painter' [La Plume, 15 May 1905], in LeRoy C. Breunig, ed., Apollinaire on Art: Essays and Reviews 1902-1918, trans. Susan Suleiman, Boston, MA, 2001, 14-16, 14 (translation modified).

5 Guillaume Apollinaire, 'From Michelangelo to Picasso' [Les Marches de Provence, February 1912], in Breunig, ed., Apollinaire on Art, 197-8, 198.

6 M. H. Abrams, The Mirror and the Lamp: Romantic Theory and the Critical Tradition, Oxford, 1953, 58-60.

7 See Maurice Shroder, Icarus: The Image of the Artist in French Romanticism, Cambridge, MA, 1961.

8 Georges Bataille, 'The Old Mole and the prefix Sur in Surhomme and Surrealism', in Georges Bataille, Visions of Excess, ed. and trans. Allan Stoekl, Minneapolis, MN, 1985, 32-44, 34.

9 Guillaume Apollinaire, The Cubist Painters, trans. Peter Read, Berkeley and Los Angeles, CA, 2004, 9.

10 E.g. Lucan, Pharsalia, trans. Jane Wilson Joyce, Ithaca, NY, 1993, 261.

11 On Turner see Ronald Paulson, 'Turner's graffiti: The sun and its glosses', in Karl Kroeber and William Walling, eds, Images of Romanticism: Verbal and Visual Affinities, New Haven and London, 1978, 167-88. On Goethe, Jung and the Nazis see Richard Noll, The Jung Cult: Origins of a Charismatic Movement, New York, 1997, 81-95.

12 Exodus 33:20.

13 Sigmund Freud, 'Psycho-analytical notes on an autobiographical account of a case of paranoia (Dementia Paranoides)', in Freud, The Standard Edition of the Complete Psychological Works of Sigmund Freud, ed. and trans. James Strachey, Vol. XII, London, 1961, 1-84, 54.

14 Freud, 'Psycho-analytical notes', 81-2.

15 Richard Payne Knight identified Priapus with the sun in his muchreprinted Account of the Remains of the Worship of Priapus lately existing in Isernia, London, 1786, 29-31. Similarly, Jacques Antoine Dulaure, Gods of Generation: History of Phallic Cults among Ancients and Moderns [1805], trans. A. F. N., Whitefish, MT, 2003, 52, promised to 'give, in detail, positive proofs of the constant union of the cult of the Phallus with that of the sun' reading mythic castrations in relation to the seasonal cycle. More than a century later, Ernest Jones wrote that: 'The themes of impotence and castration ... play a most important part in sun mythology, and indeed probably furnish the main reason for the role of the sun in early religions. The identification of the waxing and waning sun with the phallus, and particularly with the father's phallus, brought with it the projection of repressed wishes and fears relating to this organ.' Ernest Jones, On the Nightmare [1931], New York, 1951, 285.

16 Daniel Paul Schreber, Memoirs of My Nervous Illness, trans. and ed. Ida Macalpine and Richard A. Hunter, London, 1955, 95 n.44.

17 Rafael Alberti, A Year of Picasso Paintings: 1969, trans. Anthony Kerrigan, New York, 1971, 72, quoted in John Richardson, A Life of Picasso. Volume I: 1881-1906, London, 1991, 8.

18 Apollinaire, The Cubist Painters, 38.

19 John Richardson, A Life of Picasso, Volume III: The Triumphant Years 1917-1932, London, 2007, 401.

20 Michel Leiris, 'From Bataille the Impossible to the Impossible Documents', in Georges Bataille and Michel Leiris, Correspondence, ed. Louis Yvert, trans. Liz Heron, Oxford and New York, 2008, 6-21, 15.

21 Georges Bataille, 'The pineal eye', in Bataille, Visions, 79-90, 80 (translation modified). See 'L'oeil pinéal', in Georges Bataille, Oeuvres Complètes (hereafter OC) II, Paris, 1970, 21-35, 21.

22 See Martin Jay, Downcast Eyes: The Denigration of Vision in Twentieth-Century French Thought, Berkeley, CA, 1993.

23 Rosalind Krauss, 'Antivision', October, 36, Spring 1986, 147-54; Rosalind Krauss, The Optical Unconscious, Cambridge, MA and London, 1993.

24 Erwin Panofsky, 'Artist, scientist, genius: Notes on the "RenaissanceDämmerung”', in Wallace K. Ferguson et al., The Renaissance: Six Essays, New York, 1962, 121-82, 171-3.

25 See Leiris, 'From Bataille the Impossible'; Denis Hollier, 'The use value of the impossible', in Absent without Leave: French Literature under the Threat of War, trans. Catherine Porter, Cambridge, MA and London, 1997, 125-44.

26 For more on Picasso and Documents - though not from a biographical perspective - see C. F. B. Miller, 'Bataille with Picasso: Crucifixion (1930) and Apocalypse', Papers of Surrealism, 7, 2007 www. surrealismcentre.ac.uk/papersofsurrealism/journal7

27 Throughout Documents Bataille is named as General Secretary. In the 1929 run Carl Einstein is named among the Editorial Committee and Leiris in the list of 'collaborators'. See the re-edition of Documents published in 1991 by Jean-Michel Place. References to Documents are to this edition. Looking back in 1963, Leiris stated both that Bataille 'assumed the role of leader' in Documents, and that 'Documents was primarily driven by Georges-Henri Rivière, then deputy director of the Museum of Ethnography at the Trocadero, along with the German poet and cultural critic Carl Einstein ....' See Leiris, 'From Bataille the Impossible', 14. Bataille himself stated in a note unpublished in his lifetime that 'I actually edited [Documents], in agreement with Georges Henri Rivière, ... and in opposition to the titular editor, the German poet Carl Einstein ....' See Georges Bataille, 'The Publication of "A Corpse"', in Bataille and Leiris, Correspondence, 63-9, 68. As Liliane Meffre, Georges Didi-Huberman, Conor Joyce and Sebastian Zeidler have variously argued, this version of events marginalizes Einstein's contribution.

28 Georges Bataille, 'Soleil pourri', Documents, 3, 1930, 173-4 [my translation].

29 On the problematic of experience see Martin Jay, 'The limits of limitexperience', in Cultural Semantics: Keywords of Our Time, London, 1998, 62-78.

30 Georges Bataille, 'The "Lugubrious Game"' [Documents, 7, December 1929], in Bataille, Visions of Excess, 24-30, 28-9, n.1. On this and other unfinished book projects see Denis Hollier, 'About some books which Bataille did not write', trans. Boris Belay, parallax, 3: 2, 1997, 71-8.

31 Plato, The Republic Vol. 2, with an English translation by Paul Shorey, Cambridge, MA and London, 1935 509c. (Translation modified. Shorey at note (d) suggests 'What a comble!' for huperbolès.)

32 Hollier, 'The use value of the Impossible'; Leiris, 'From Bataille the Impossible', 15.

33 Plato, Republic, 506e.

34 Martin Heidegger, The Essence of Truth: On Plato's Cave Allegory and Theaetetus, trans. Ted Sadler, London, 2002, 73.

35 Heidegger, The Essence of Truth, 70.

36 Jacques Derrida, 'Force and signification', in Derrida, Writing and Difference, trans. Alan Bass, London, 1978, 3-30, 27.

37 Jacques Derrida, 'The principle of reason: The university in the eyes of its pupils', Diacritics, 13: 3, 1987, 4. Cf. John McCumber, 'Derrida and the closure of vision', in David Michael Levin, ed., Modernity and the Hegemony of Vision, Berkeley, CA and London, 1993, 186-217.

38 Plato, Republic, 516b (translation modified according to that of Desmond Lee, London, 1987).

39 Plato, Republic, 517b.

40 Plato, Republic, 517b (translation modified according to that of John Llewellyn Davies and David James Vaughan, Ware, 1997).

41 John Sallis, The Verge of Philosophy, Chicago, IL and London, 2008, 45

42 Sallis, The Verge of Philosophy, 39.

43 Sallis, The Verge of Philosophy, 46.

44 Platon, L'Etat, ou la République de Platon, trans. Jean-Nicolas Grou, Paris, 1842,303 . This 1765 translation was republished in the Oeuvres complètes de Platon, eds, Emmanuel Chauvet and Amédée Saisset, Paris, 1878-1918.

45 Opinion is ugly and blind in Book VI. In Book VII the prisoner is violently dragged up into the sunlight, where he experiences the temporary bedazzlement as pain. See Plato, Republic, 506c-d; 515c.

46 Voltaire, Oeuvres de Voltaire, ed. Adrien Beuchot, Paris, 1829-40, XXX, 265.

47 Michel Foucault, History of Madness, trans. Jean Khalfa, London, 2006, 243.

48 Foucault, History of Madness, 244.

49 Jacques Derrida, Positions, trans Alan Bass, London, 2002, 85, n. 35

50 'Rotten Sun' was republished in 1968 in an anthology of Bataille's Documents pieces, but Derrida's one reference to it, in 'White mythology', cites the first 1970 volume of the Oeuvres completes. That said, he was aware of Documents in 1967, if only through Raymond Queneau's retrospective account of Bataille's 'first confrontations with Hegel'. (See Raymond Queneau, 'Premières confrontations avec Hegel', Critique, 195-6, August-September 1963, 694-700. Derrida refers to this in a note to the 1967 text, 'From restricted 
to general economy: A Hegelianism without reserve', in Derrida, Writing and Difference, trans. Alan Bass, London, 1978, 251-77, 334 n.7. For the reference to 'Rotten Sun' see 'White mythology: Metaphor in the text of philosophy', in Derrida, Margins of Philosophy, trans. Alan Bass, Chicago, IL, 1982, 207-71, 271 n.87; for the anthology see Georges Bataille, Documents, ed. Bernard Noël, Paris, 1968. Interest in Bataille was spiking in the late 1960s; 'Plato's pharmacy' appeared in the preceding numbers of Tel Quel to that which carried Bataille's previously unpublished Documents-era polemic, "The "Old Mole" and the Prefix Sur in the Words Surhomme and Surréaliste'. See Derrida, 'Le pharmacie de Platon', Tel Quel, 32, 3-48; Tel Quel, 33, Spring 1968, 1859; Bataille, 'La "vieille taupe" et le préfixe sur dans les mots surhomme et surréaliste’, Tel Quel, Summer 1968, 5-17.

51 He refers to it in 1967. See Jacques Derrida, 'De l'économie restreinte à l'économie générale, un Hegelianisme sans réserve', in L'Ecriture et la différence, Paris, 1967, 369-407, 400-1, n.1.

52 Bataille, "The "Old Mole".

53 Jacques Derrida, Dissemination, 110.

54 Georges Bataille, Inner Experience, trans. Leslie Anne Boldt, Albany, NY, 1988, 108.

55 Bataille, Inner Experience, 110

56 Bataille, Inner Experience, 111

57 Derrida, 'Plato's pharmacy', 82-3.

58 Derrida, 'Plato's pharmacy', 92.

59 Plato, Republic, 506e.

60 Plato, Republic, 507a.

61 Derrida, 'Plato's pharmacy', 88.

62 Derrida, 'Plato's pharmacy', 88-9.

63 Plato, Republic, 509b.

64 Derrida, 'Plato's pharmacy', 164-6.

65 Sallis, The Verge of Philosophy, 85-6.

66 Krauss, 'Antivision', 150.

67 Hans Blumenberg, 'Light as a metaphor for truth: At the preliminary stage of philosophical concept formation', in Levin, ed., Modernity and the Hegemony of Vision, 30-62, 45.

68 Quoted in Blumenberg, 'Light as a metaphor for truth', 59, n.68.

69 On Bataille and this tradition see Peter Tracey Connor, Georges Bataille and the Mysticism of Sin, Baltimore, MD and London, 2000, 11.

70 Connor, Georges Bataille and the Mysticism of Sin, 28.

71 Albert Camus, 'An absurd reasoning' [from The Myth of Sisyphus], trans. Justin O’Brien, in Paul S. MacDonald, The Existentialist Reader: An Anthology of Key Texts, Edinburgh, 2000, 151-83, 161.

72 See Ramona Fotiade, Conceptions of the Absurd: From Surrealism to the Existential Thought of Chestov and Fontaine, Oxford, 2001.

73 Jacques Derrida, 'How to avoid speaking: Denials', in Harold Coward and Toby Foshay, Derrida and Negative Theology, Albany, NY, 1992, 73-142, 101.

74 Rodolphe Gasché, 'God, for example', in Inventions of Difference, Cambridge, MA, 1994, 150-70, 165.

75 See Bataille. "The "Old Mole".

76 Denis Hollier, 'About some books', 76.

77 Derrida, 'From restricted to general economy', 271.

78 Derrida, 'From restricted to general economy', 261.

79 Georges Bataille, 'The use value of D.A.F. de Sade (An Open Letter to My Current Comrades)', in Bataille, Visions, 91-102, 97.

80 Guillaume Apollinaire, 'Zone', in Apollinaire, Selected Writings of Guillaume Apollinaire, ed. and trans. Roger Shattuck, New York, 1971, $116-27,126$.

81 For a useful overview of solarism see Richard M. Dorson, 'The eclipse of solar mythology', The Journal of American Folklore, 68: 270, OctoberDecember 1955, 393-416.

82 Anatole France, The Garden of Epicurus [1895], trans. Alfred Allinson, New York, 1923, 214, 201.

83 Jacques Derrida, 'White mythology', 214. The essay was originally published in Poétique, 5, 1971.

84 Derrida, 'White mythology', 271 n. 87.

85 Derrida, 'White mythology', 226.

86 Denis Hollier, 'The use value of the Impossible', in Absent without Leave, 125-144, 131.

87 Plato, Republic, 507a.

88 André Breton, 'Le surréalisme et la peinture', La Révolution surréaliste, 4,
1925, 26-30

89 Bataille, 'The "Lugubrious Game”, 24 (translation modified).

90 Aristotle, Poetics, ed. and trans. Stephen Halliwell, Cambridge, MA and London, 1995, 1457b. Cf. Paul Ricoeur, The Rule of Metaphor: The Creation of Meaning in Language, trans. Robert Czerny, London and New York, 2003, $17-18$.

91 Aristotle, Poetics, 1459a (translation modified).

92 Max Nänny and Olga Fischer, 'Iconicity: Literary texts', in Keith Brown, ed., Encyclopedia of Language and Linguistics, Amsterdam and London, 2006, 462-72.

93 Yve-Alain Bois, 'Figure', in Yve-Alain Bois and Rosalind Krauss, Formless: A User's Guide, New York, 1997, 79-86.

94 Georges Didi-Huberman, La Ressemblance informe, ou le gai savoir selon Georges Bataille, Paris, 1995, 13.

95 Martin Heidegger, An Introduction to Metaphysics, New York, 1961, 155. Cf. David Michael Levin, 'Decline and fall: Ocularcentrism in Heidegger's reading of the history of metaphysics', in Levin, Modernity and the Hegemony of Vision, 186-217.

96 Patrick ffrench describes the operation of the informe in Histoire de l'oeil as 'an operation of displacement within that of resemblance, of metonymy which collapses the verticality of metaphor from within, a copula which is the mark not of equivalence but of slippage.' Patrick ffrench, The Cut / Reading Bataille's Histoire de l'oeil, Oxford, 1999, 27.

97 John R. Searle, 'Metaphor', in Andrew Ortony, ed., Metaphor and Thought, Cambridge, 1993, 85-111, 96.

98 Didi-Huberman, La Ressemblance informe, 193.

99 Georges Bataille, 'The Jesuve', in Bataille, Visions, 73-8, 75 (translation modified).

100 Fyodor Dostoevsky, The Idiot, trans. Constance Garnett, New York, 2004, 207-8.

101 A. Radovici et al., 'Epilepsie réflexe provoquée par excitations optiques des rayons solaires', Revue neurologique, 1, 1932, 1305-8.

102 Amy Hollywood, Sensible Ecstasy : Mysticism, Sexual Difference, and the Demands of History, Chicago and London, 2002, 38.

103 The sole surviving detailed account of the taurobolium is in Prudentius, Crowns of Martyrdom 10.1001-50; see the extract in Mary Beard, John North and Simon Price, eds, Religions of Rome: Volume II, A Sourcebook, Cambridge, 1998, 161.

104 Franz Cumont, Les Religions orientales dans le paganisme romain, Paris, 1929, 104.

105 Salomon Reinach, 'La morale du Mithaïsme', Cultes, mythes et religions, Vol. II, 1905-1923, 220-33.

106 Jean-Luc Nancy, 'The unsacrificeable', trans. Richard Livingstone, Yale French Studies, 79, 1991, 20-38, 29.

107 Nancy, 'The unsacrificeable', 25.

108 Nancy, 'The unsacrificeable', 27.

109 Nancy, 'The unsacrificeable', 37.

110 'In fact, the phenomena for which psychoanalysis accounts can be reduced in the final analysis to drives whose goal is expressed in psychological terms but whose source is of a somatic nature. There is no question here of a matter-spirit dualism ....' Georges Bataille and Raymond Queneau, 'The critique of the foundations of the Hegelian dialectic', La Critique sociale, 5, March 1932, 209-14; translated in Bataille, Visions, 105-15, 113.

111 Georges Bataille, 'Architecture', OC I, 171-2, 171.

112 Georges Bataille, 'L'Esprit moderne et le jeu des transpositions', Documents, 8, 1930 [1931], 49-52

113 Bataille: 'By inner experience I understand that which one usually calls mystical experience: the states of ecstasy, of rapture, at least of meditated emotion. But I am thinking less of confessional experience, ... than of an experience laid bare, free of ties, even of an origin, of any confession whatever. This is why I don't like the word mystical.' Bataille, Inner Experience, 3.

114 Bataille states that Borel gave him the photograph, in his last book, The Tears of Eros (206-7). The Sinologist Jérôme Bourgon has recently questioned this account, and Bataille's authorship of The Tears of Eros. See Timothy Brook, Jérôme Bourgon and Gregory Blue, Death by a Thousand Cuts, Cambridge, MA, 2008, 222-42. On Bataille and the lingchi photograph, see Antony Hudek, 'The sensive image: De-thinking the figure with Bataille and Levinas', Image \& Narrative, 18, 2007 http://www.imageandnarrative.be/inarchive/thinking_ 


\section{F. B. Miller}

pictures/hudek.htm.

115 Bataille, Inner Experience, 119-20.

116 Bataille, Inner Experience, 117.

117 Connor, Georges Bataille and the Mysticism of Sin, 166 n.3.

118 'Sacrificial mutilation and the severed ear of Vincent Van Gogh', in Bataille, Visions, 61-72, 67.

119 Bataille, 'The Jesuve', 74.

120 Bataille, 'The "Lugubrious Game”, 24 (translation modified).

121 See Erwin Panofsky, Idea: A Concept in Art Theory, trans. Joseph Peake, New York, 1975

122 Georges Bataille, 'The pineal eye', 81.

123 See Richard D. E. Burton, “Baudelaire's S/Z: “Sisina” and the Domestication of the Feminine', Modern Philology, 92: 1, August 1994, 64-72.

124 David Batchelor, “'This liberty and this order”: Art in France after the First World War', in Briony Fer, David Batchelor, Paul Wood, Realism, Rationalism, Surrealism: Art between the Wars, New Haven and London, 1993, $2-86,75$.

125 The Trésor de la langue du XIXe et du XXe siècles (1789-1960) gives the first instance as 1936; the Grand Robert as 1937.

126 'The process of appropriation is thus characterised by a homogeneity (static equilibrium) of the author of the appropriation ..., whereas excretion presents itself as the result of a heterogeneity, and can move in the direction of an ever greater heterogeneity, liberating impulses whose ambivalence is more and more pronounced.' Bataille, 'The Use Value of D.A.F. de Sade', 95.

127 Georges Bataille, 'Dream', in Bataille, Visions, 3-4, 4.

128 Bataille, 'Dream', 4.

129 Zdenko Reich, 'Soleil', Documents, 7, 1930, 433-6; translated in Encyclopaedia Acephalica, London, 1995, 80-2.

130 The phrase is from 'Group psychology and the analysis of the ego', SE XVIII, 135.

131 Marcel Detienne, The Creation of Mythology, trans. Margaret Cook, Chicago, IL, 1986, xi.

132 Gianni Vattimo, 'Myth rediscovered', in The Transparent Society, Cambridge, 1992, 28-44.

133 Jean-Luc Nancy, 'Myth interrupted', in The Inoperative Community, ed. and trans. Peter Connor, Minneapolis, MN, 1991, 43-70, 45.

134 Jean-Luc Nancy and Philippe Lacoue-Labarthe, 'The Nazi myth', trans. Brian Holmes, Critical Inquiry, 16: 2, Winter 1990, 291-312, 297.

135 Georges Bataille, 'The pineal eye', in Bataille, Visions, 79-90, 80 (translation modified). See Bataille, 'L'Oeil pineal (I)', 21.

136 Bataille, 'The pineal eye', 81.

137 Georges Bataille, 'Van Gogh as Prometheus' [1937], trans. Annette Michelson, October, 36, Spring 1986, 58-60.

138 Jean-Pierre Vernant, Myth and Society in Ancient Greece, London, 1982, $186-7$.

139 Bataille, 'The "Old Mole", 42.

140 Gillian Beer, “"The death of the sun”: Victorian solar physics and solar myth', in J. B. Bullen, ed., The Sun is God: Painting, Literature and Mythology in the Nineteenth Century, Oxford, 1989, 159-80, 165.

141 Georges Bataille, Theory of Religion, trans. Robert Hurley, New York, 1992, 53.

142 Sigmund Freud, Essais de psychanalyse, trans. S. Jankélévitch, Paris, 1927.

143 Sigmund Freud, The Ego and the Id, in The Standard Edition of the Complete Psychological Works of Sigmund Freud, Vol. XIX, ed. and trans. James Strachey, London, 1961, 1-66, 37.

144 'The super-ego is always close to the id and can act as its representative vis-à-vis the ego. It reaches deep down into the id and for that reason is farther from consciousness than the ego is.' Freud, The Ego and the Id, $48-9$.

145 'After sublimation the erotic component no longer has the power to bind the whole of the destructiveness that was combined with it, and this is released in the form of an inclination to aggression and destruction. This defusion would be the source of the general character of harshness and cruelty exhibited by the ideal -its dictatorial "Thou shalt".' Freud, The Ego and the Id, 54-5.

146 Jacques Derrida, Of Grammatology, trans. Gayatri Chakravorty Spivak, Baltimore, MD, 1997, 71.

147 Freud, The Ego and the Id, 56-7.

148 Freud, The Ego and the Id, 42.
149 Bataille, 'Sacrificial mutilation', 63.

150 Georges Bataille, 'Sacrificial mutilation', 66 (translation modified, my emphasis).

151 Freud, The Ego and the Id, 34.

152 Freud, The Ego and the Id, 57.

153 Georges Bataille, 'L’oeil pinéal (4)', OCII, 41-7, 45-6.

154 Friedrich Nietzsche, Beyond Good and Evil, n. 230, trans. Helen Zimmern, Buffalo, NY, 1989, 180-1.

155 Friedrich Nietzsche, The Birth of Tragedy out of the Spirit of Music, trans. Michael Tanner, London, 1993, 50

156 Bataille, 'The Jesuve', 74.

157 Jacques Derrida, 'Economimesis', trans. Richard Klein, Diacritics, 11, 2, Summer, 1981, 2-25, 12.

158 Cf. Denis Hollier, 'Bataille's tomb', in Hollier, Absent Without Leave, $46-68,65-8$ 